\title{
Pengaruh Kualitas Laporan Keuangan Terhadap Kinerja Usaha UMKM
}

\author{
Yunita Eriyanti Pakpahan \\ Program Studi Akuntansi, Universitas Quality Berastagi \\ Email: yunitaeriyantipakpahan@gmail.com
}

\begin{abstract}
Abstrak
Sektor usaha kecil menengah (UMKM) merupakan salah satu poros kebangkitan perekonomian nasional yang memiliki permasalahan dalam hal penerapan akuntansi sesuai dengan SAK ETAP. Peran SAK ETAP dalam memberikan informasi mengenai efektivitas dan efisiensi kegiatan ekonomi suatu usaha. Tujuan penelitian ini adalah untuk menganalisis pengaruh kualitas laporan keuangan terhadap kinerja usaha UMKM. Data dari penelitian ini diperoleh dari kuesioner dengan responden pengusaha UMKM di kota Medan. Jumlah respondensebanyak 100 yang pengusaha UMKM. Data yang diperoleh kemudian dianalisi dengan menggunakan SPSS. Hasil penelitian ini menunjukkan bahwa kualitas laporan keuangan berpengaruh signifikan terhadap kinerja usaha UMKM.
\end{abstract}

Kata kunci: Kualitas Laporan Keuangan; Kinerja; UMKM

\section{Impact of the Quality of Financial Statements on the Business Performance of MSMEs}

\begin{abstract}
The small and medium business sector (SMEs) is one of the axis of the rise of the national economy that has problems in applying accounting in accordance with SAK ETAP. The role of SAK ETAP in providing information about the effectiveness and efficiency of a business's economic activities. The purpose of this study is to analyze the effect of the quality of financial statements on MSMEs business performance. Data from this study were obtained from a questionnaire with respondents of MSMEs entrepreneurs in the city of Medan. The number of respondents is 100 who are MSME entrepreneurs. The data obtained was then analyzed using SPSS. The results of this study indicate that the quality of financial statements has a significant effect on SMEs business performance.
\end{abstract}

Keyword: Financial Statement's Quality; Performance; MSMEs

\section{Pendahuluan}

Tingkat pertumbuhan UMKM saat ini mendapat perhatian oleh pemerintah dengan memberikan berbagai kemudahan bagi pelaku usaha baik dari sektor permodalan maupun perpajakan. UMKM diketahui sangat memberikan kontribusi yang besar dan krusial bagi perekonomian secara makro. Pada tahun 2020 jumlah UMKM yang tersebar diseluruh Indonesia sebanyak 26.422.256 (Badan Pusat Statistik, 2016). Dari angka tersebut terdapat potensi yang sangat besar apabila usaha tersebut dikembangkan dan ditingkatkan sehingga memberikan konstribusi yang besar bagi perekonomian Indonesia. Sesuai dengan pernyataan (Martauli, 2019), keberadaan Usaha Mikro, Kecil, dan Menengah (UMKM) di Indonesia memiliki peran dalam meningkatkan perekonomian negara. Keberadaan UMKM hampir dapat dijumpai di sepanjang jalan dan juga se-makin tahun semakin bermunculan UMKM. Artinya dari tahun ke tahun UMKM mengalami peningkatan. Meningkatnya perkembangan UMKM diharapkan dapat memberikan kontribusi dalam upaya penanggulangan masalah-masalah ekonomi dan sosial dalam negeri.

DOI: 10.25273/inventory.vxix.7436

Copyright (C) 2021 Penulis

Sume rights reserved. 
Agar keberadaan UMKM bisa bertahan dan tetap eksis maka UMKM perlu untuk mendapatkan perhatian berkaitan dengan kemajuan dan perkembangan UMKM. Apalagi dalam menghadapi Masyarakat Ekonomi ASEAN yang dimulai pada tahun 2015, maka UMKM diharapkan untuk dapat semakin produktif dan berdaya saing. Namun UMKM Indonesia harus mewaspadai persaingan yang semakin tajam. Karena UMKM di Indonesia memiliki peran strategis. Selain itu juga, UMKM mampu menyerap tenaga kerja sehingga memperkecil angka pengangguran, membentuk produk domestic bruto dan mampu menjadi jaring pengaman untuk masyarakat yang berpendapatan rendah. Namun permasalahan yang timbul di lapangan adalah masih banyaknya pelaku usaha yang menemukan kesulitan dalam pemberian kredit oleh perbankan disebabkan oleh kualitas laporan keuangan yang dihasilkan. Menurut (Mulyani, 2014) bahwa UMKM pada umumnya merupakan usaha industri keluarga yang mana konsumen adalah dikalangan menengah kebawah. Akan tetapi, UMKM cenderung mampu lebih bertahan jika dibandingkan dengan perusahaan besar. Dalam menghadapi tantangan, UMKM masih rendah dan memiliki kelemahan. Menurut Benjamin (1990) bahwa kelemahan UMKM yaitu masih rendahnya pendidikan dan pengetahuan sehingga dapat menyebabkan kurangnya pemahaman terhadap Standar Akuntansi Keuangan (SAK). Sedangkan Muntoro (1990), penyebab rendahnya penyusunan laporan keuangan dikarenakan tidak mewajibkan untuk penyusunan laporan keuangan.

Laporan keuangan merupakan output proses akuntansi dalam menyediakan informasi keuangan dalam suatu usaha yang bermanfaat untuk pengambilan keputusan (Ningtiyas, 2017). Selain kendala utama yang dihadapi oleh UMKM yaitu permodalan yang masih kurang. Namun masih banyak UMKM yang berlum dapat mengakses kebijakan pemerintah dalam permodalan. Diakibatkan UMKM masih cenderung sepele dalam membuat laporan keuangan yang dianggap tidak penting. Salah satu tolak ukur kinerja pelaku usaha tersebut dapat dilihat dari kualitas laporan keuangan dalam bentuk pencatatan atau pembukuan yang ada dalam usaha tersebut. Kelemahan ini dibuktikan dari hasil penelitian BI Cabang Medan bekerja sama dengan Universitas Sumatera Utara (USU) pada Oktober 2008 diketahui hanya 22,5\% pelaku UKM yang memiliki laporan keuangan dan 87,8\% pelaku UKM yang menyusun laporan keuangan secara tidak layak. Di era industri 4.0 pelaku usaha umkm harus mampu meningkatkan kualitas laporan keuangan karena besar kemungkinan dapat membantu mereka dalam hal pemberian pinjaman modal oleh perbankan atau non perbankan lainnya. Dalam penelitian ini dilakukan analisis kualitas laporan keuangan terhadap kinerja usaha umkm. Tujuan dilakukan penelitian ini adalah Untuk menganalisis pengaruh kualitas laporan keuangan terhadap kinerja usaha UMKM.

\section{Metode Penelitian}

Penelitian ini dilakukan di Medan Provinsi Sumatera Utara pada bulan November sampaiDesember 2019. Populasi yang diteliti adalah pelaku usaha UMKM. Adapun jumlah sampel pada penelitian ini sebanyak 100 pelaku usaha UMKM. Metode penentuan sampel dengan menggunakan purposive sampling. Data penelitian ini berupa data primer. Data primer adalah data yang dikumpulkan secara langsung kepada responden dengan menggunakan alat bantu kuesioner (Futri dan Juliarsa, 2014). Pengumpulan data primer digunakan dengan alat bantu kuesioner/angket.

Definisi Operasional Perkembangan UMKM sebagai tingkat pendapatan UMKM dengan indikator dari unsur pendapatan dan sumber pendapatan. Instrumen yang digunakan terdiri dari 12 item pertanyaan yang disusun oleh (Baridwan dan Kresnawati, 2016). Definisi operasional kualitas laporan keuangan menurut (Mulyani, 2014) menyatakan bahwa kualitas laporan keuangan untuk menilai seberapa jauh dan lengkapnya catatan keuangan yang disiapkan sampai membentuk laporan keuangan, kedisiplinan dalam mencatat setiap transaksi (tidak ada transaksi yang terlewatkan dari catatan akuntansi), komponen laporan keuangan dan standar akuntansi yang dipakai. Instrumen yang digunakan terdiri dari 8 item pertanyaan yang disusun oleh (Rudiantoro dan Siregar, 2012). Skala yang digunakan adalah skala likert yaitu 1 sampai 5 dengan lima skala pengukuran mulai skor STS (sangat tidak setuju), TS (tidak setuju), N (netral), S (setuju), ST (sangat setuju). Pengujian hipotesis penelitian ini menggunakan regresi berganda dengan bantuan perangkat lunak SPSS 16. Model regresi dipilah untuk menganalisis hubungan variabel dependen dengan beberapa variabel independen. Adapun model penelitian sebagai berikut:

$$
Y=\alpha+\beta 1 X 1+\varepsilon
$$


Keterangan:

$\mathrm{Y} \quad=$ Kualitas Laporan Keuangan

$\alpha \quad=$ konstanta

$\beta \quad=$ koefisien regresi

$\mathrm{X} 1=$ Kinerja UMKM

$\epsilon \quad=$ Kesalahan residual

\section{Hasil dan Pembahasan Uji Validitas}

Uji validitas merupakan uji yang didasarkan pada penelitian ini, dengan menggunakan kriteria untuk menyatakan bahwa instrumen yang digunakan dianggap valid atau layak untuk dapat digunakan untuk melakukan pengujian hipotesis. Tabel 1, menunjukan bahwa pengujian validitas data dengan menggunakan Pearson Correlation. Jika dilihat hasil uji validitas pada tabel 1, dapat diketahui dari 8 item yang digunakan bahwa seluruhnya memiliki nilai pearson correlation lebih dari 0,05 (taraf 5\%). Artinya variabel yang digunakan valid untuk tahap selanjutnya.

Tabel 1. Hasil Uji Validitas

\begin{tabular}{cccc}
\hline $\begin{array}{c}\text { Item } \\
\text { Pernyataan }\end{array}$ & $\begin{array}{c}\mathbf{R} \\
\text { hitung }\end{array}$ & $\begin{array}{c}\mathbf{R} \\
\text { tabel }\end{array}$ & Keterangan \\
\hline KLP1 & 0,653 & 0,1966 & Valid \\
KLP2 & 0,604 & 0,1966 & Valid \\
KLP 3 & 0,558 & 0,1966 & Valid \\
KLP 4 & 0,654 & 0,1966 & Valid \\
KLP 5 & 0,715 & 0,1966 & Valid \\
KLP 6 & 0,638 & 0,1966 & Valid \\
KLP 7 & 0,636 & 0,1966 & Valid \\
KLP 8 & 0,684 & 0,1966 & Valid \\
\hline
\end{tabular}

Sumber : Data diolah SPSS, 2019

\section{Uji Reliabilitas}

Reliabilitas merupakan alat yang digunakan untuk mengukur kuesioner yang digunakan oleh peneliti. Kuesioner yang digunakan dikatakan reliabel jika mampu konsisten terhadap pertanyaan yang digunakan konsisten dengan jawaban responden. Untuk mengetahui reliabilitas

pada penelitian ini, maka digunakan Cronbach Alpha yang terdapat pada aplikasi SPSS. Reliabelkonstruk yang digunakan jika dapat memberikan nilai Cronbach Alpha $>0,60$. Hasil uji reliabilitas pengaruh kualitas keuangan dapat dilihat pada Tabel 2 berikut ini.

Tabel 2. Hasil Uji Reliabilitas Data

\begin{tabular}{lccc}
\hline Variabel & $\begin{array}{l}\text { Cronbach } \\
\text { alpha }\end{array}$ & $\begin{array}{l}\text { Koefisien } \\
\text { Cronbach } \\
\text { Alpha }\end{array}$ & Keterangan \\
\hline $\begin{array}{l}\text { KUALITAS LAPORAN } \\
\text { KEUANGAN }\end{array}$ & 0,6 & 0,792 & Reliabel \\
KINERJA & 0,6 & 0,799 & Reliabel \\
\hline
\end{tabular}

Sumber : Data diolah SPSS, 2019

Tabel 2, menunjukkan bahwa hasil uji reliabilitas nilai kualitas laporan keuangan dan kinerja memilki nilai >0,60, masing masing yaitu untuk laporan keuangan sebesar 0,792 dan kinerja 0,799. Sehingga dapat disimpulkan bahwa instrument kuesioner pada penelitian ini layak (reliable) untuk dipergunakan.

\section{Statistik Deskriptif}

Objek dalam penelitian ini adalah UMKM Kota Medan yang terdaftar di Dinas Koperasi UMKM. Pengumpulan data dilakukan dengan menggunakan metode distribusi langsung (direct distribution method), yaitu mendatangi para responden secara langsung untuk menyerahkan ataupun mengumpulkan kembali kuesioner. Kuesioner yang disebar kepada responden sebanyak 100 kuesioner. Hasil analisis statistik 
deskriptif dapat dilihat pada Tabel 3 berikut ini:

Tabel 3. Hasil Statistik Deskriptif

\begin{tabular}{|c|c|c|c|c|c|}
\hline & $\mathrm{N}$ & Minimum & Maximum & Mean & $\begin{array}{c}\text { Std. } \\
\text { Deviation }\end{array}$ \\
\hline Kualitaslk & 100 & 20.00 & 40.00 & 33.3000 & 3.83630 \\
\hline Kinerja & 100 & 19.00 & 39.00 & 33.4700 & 3.90145 \\
\hline Valid N (Listwise) & 100 & & & & \\
\hline
\end{tabular}

Tabel 3, pengujian statistik diketahui bahwa nilai minimum kualitas laporan keuangan sebesar 20, nilai maksimum 40 dan nilai rata-rata (mean) sebesar 33.300 dengan standar deviasi 3.836. Nilai rata-rata 33.300 menunjukkan bahwa besarnya kualitas laporan keuangan sebesar 33.300. Nilai rata-rata dan nilai standar deviasi kualitas laporan keuangan ini menunjukkan bahwa terdapat penyebaran data yang baik karena nilai rata-ratanya lebih besar dari pada standar deviasi. Berdasarkan pengujian statistic diketahui bahwa nilai minimum kinerja sebesar 19, nilai maksimum 39 dan nilai rata-rata (mean) sebesar 33.47 dengan standar deviasi 3.90145. Nilai ratarata 33.47 menunjukkan bahwa besarnya kinerja sebesar 33.47. Nilai rata-rata dan nilai standar deviasi kinerja ini menunjukkan bahwa terdapat penyebaran data yang baik karena nilai rataratanya lebih besar dari pada standar deviasi.

\section{Uji Asumsi Klasik}

\section{Uji normalitas}

Metode yang handal adalah dengan melihat normal probability plot yang membandingkan distribusi kumulatif dari distribusi normal. Distribusi normal akan membentuk satu garis lurus diagonal. Jika distribusi data residual normal, maka garis yang menggambarkan data sesungguhnya akan mengikuti garis diagonalnya. Uji normalitas pada penelitian ini dapat dilihat pada gambar 1.

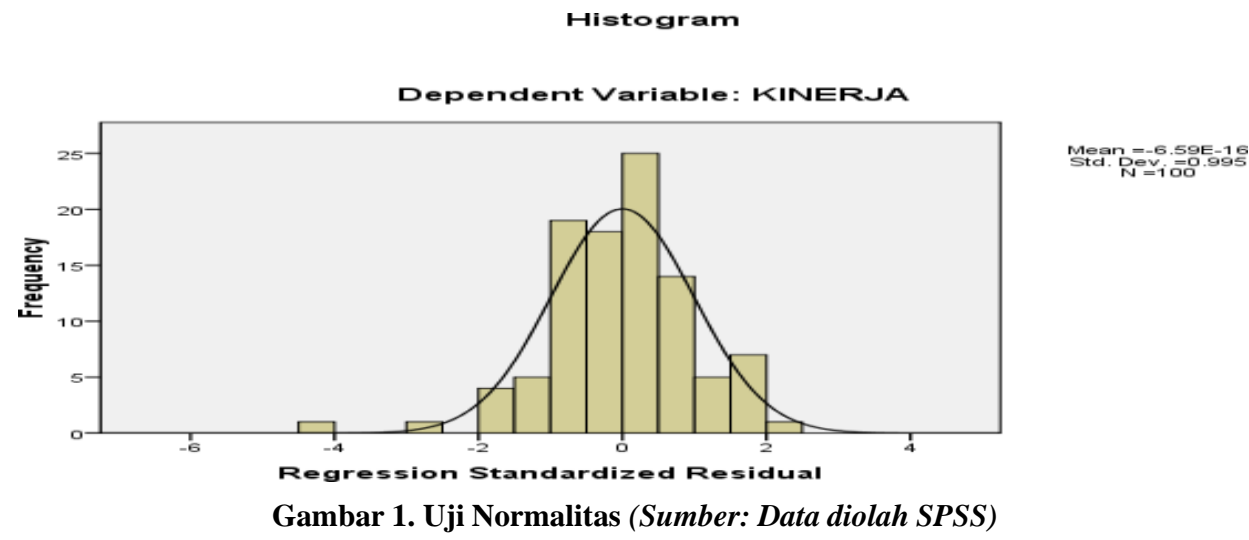

Gambar 1 dapat dilihat bahwa data tersebar di sekitar garis lurus tersebut (tidak terpencar jauh dari garis lurus). Maka dapat disimpulkan bahwa persyaratan normalitas data pada penelitian ini telah dapat terpenuhi.

\section{Uji multikolinearitas}

Nilai cutoff yang umum dipakai untuk menunjukkan adanya multikolinearitas adalah nilai Tolerance $\leq 0,10$ atau sama dengan nilai VIF $\geq 10$ yang dapat dilihat pada tabel 4 .

Tabel 4. Hasil uji multikolinearitas

\begin{tabular}{|l|c|r|l|l|}
\hline Model & $\begin{array}{c}\text { Unstandardized } \\
\text { Coefficients }\end{array}$ & $\begin{array}{c}\text { Std } \\
\text { Coefficients }\end{array}$ & $\begin{array}{c}\text { Keterangan } \\
\text { Collinearity } \\
\text { Statistics }\end{array}$ & \\
\hline
\end{tabular}




\begin{tabular}{|c|c|c|c|c|c|c|}
\hline & B & Std. Error & Beta & $\begin{array}{l}\text { Toleranc } \\
\mathrm{e}\end{array}$ & VIF & \\
\hline $1 \quad$ (Constant) & 14.342 & 2.842 & & & & \begin{tabular}{|l} 
Tidak terjadi \\
Multikolinearitas
\end{tabular} \\
\hline $\begin{array}{l}\text { KUALITAS } \\
\text { LK }\end{array}$ & .574 & .085 & .565 & $\begin{array}{l}1.00 \\
0\end{array}$ & $\begin{array}{l}1.00 \\
0\end{array}$ & \\
\hline
\end{tabular}

(Sumber: Data diolah SPSS)

\section{Uji Autokorelasi}

Uji autokorelasi bertujuan untuk menguji apakah dalam sebuah regresi linear ada korelasiantara kesalahan pengganggu (error) pada periode t dengan kesalahan pengganggu pada periode sebelumnya. Autokorelasi pada penelitian ini dideteksi dengan nilai Durbin-Watson. Menurut (Rudiantoro dan Siregar, 2012) batas tidak terjadi terjadinya autokorelasi adalah angka Durbin-Watson berada antara -2 sampai dengan +2 . Adapun hasil pengujian autokorelasi pada penelitian ini dapat dilihat pada tabel 5 .

Tabel 5. Hasil Uji Autokorelasi

\begin{tabular}{|l|r|r|r|r|r|}
\hline Model & $\mathrm{R}$ & $\mathrm{R}$ Square & $\begin{array}{c}\text { Adjusted R } \\
\text { Square }\end{array}$ & $\begin{array}{c}\text { Std. Error of the } \\
\text { Estimate }\end{array}$ & Durbin-Watson \\
\hline 1 & $.565^{5}$ & .319 & .312 & 3.23595 & 2.000 \\
\hline
\end{tabular}

a. Predictors: (Constant), KUALITASLK

b. Dependent Variable: KINERJA

(Sumber: Data diolah SPSS)

\section{Analisis Regresi Linear Berganda}

Dalam penelitian ini untuk menjawab pertanyaan penelitian, maka digunakan suatu model analisis regresi berganda, yaitu menggunakan variabel pemahaman akuntansi, pemahaman ketentuan perpajakan, dan transparansi dalam pajak untuk menjelaskan variabel kepatuhan wajib pajak badan. Pada Tabel 6 berikut hasil dari regresi berganda.

Tabel 6. Hasil Pengaruh Kualitas Laporan Keuangan TerhadapKinerja Usaha UMKM

\begin{tabular}{|c|c|c|c|c|c|c|}
\hline \multirow{2}{*}{\multicolumn{2}{|c|}{ Model }} & \multicolumn{2}{|c|}{ Unstandardized Coefficients } & \multirow{2}{*}{$\begin{array}{c}\begin{array}{c}\text { Standardized } \\
\text { Coefficients }\end{array} \\
\text { Beta } \\
\end{array}$} & \multirow[b]{2}{*}{$\mathrm{t}$} & \multirow[b]{2}{*}{ Sig. } \\
\hline & & $\mathrm{B}$ & Std. Error & & & \\
\hline \multirow[t]{2}{*}{1} & (Constant) & 14.342 & 2.842 & & 5.047 & .000 \\
\hline & KUALITASLK & .574 & .085 & .565 & 6.776 & .000 \\
\hline
\end{tabular}

a. Dependent Variable: KINERJA

(Sumber: Data diolah SPSS)

Berdasarkan tabel diatas, persamaan regresi yang dihasilkan adalah:

$\mathbf{Y}=a+b_{1} X_{1}+e$

$\mathrm{Y}=14,342+0,574 X_{1}+e$

Persamaan regresi diatas mempunyai makna sebagai berikut:

a. Nilai konstanta (a) sebesar 14,342. Artinya adalah apabila variabel independen diasumsikan nol (0), maka kepatuhan wajib pajak sebesar 14,342.

b. Nilai koefisien regresi variabel kualitas laporan keuangan sebesar 0,574. Artinya adalah bahwa setiap peningkatan kualitas laporan keuangan sebesar 1 satuan maka akan meningkatkan kinerja sebesar 0,574 dengan asumsi variabel lain tetap.

\section{Pengaruh Kualitas Laporan Keuangan Terhadap Kinerja UMKM}

Tabel 6 menunjukkan bahwa nilai signifikan kualitas laporan keuangan sebesar 0,00, nilai ini signifikan apabila dibandingkan dengan tingkat signifikansinya, yaitu $\alpha=0.05$, dimana $\mathbf{0 , 0 0}<0.05$. Selain itu, diperoleh t_hitung sebesar 6.776 dan t_tabel sebesar 1.984. Dengan demikian tampak bahwa t_hitung > t_tabel, maka H1 diterima. Oleh karena itu, disimpulkan bahwa kualitas laporan keuangan berpengaruh secara parsial terhadap kinerja usaha UMKM. 


\section{Uji Simultan}

Tabel 7, menunjukkan bahwa hasil uji pengaruh simultan pada penelitian pengaruh kualitas laporan keuangan terhadap kinerja UMKM.

Tabel 7. Uji Simultan

ANOVA ${ }^{b}$

\begin{tabular}{|ll|r|r|r|r|c|}
\hline \multicolumn{1}{|l|}{ Model } & \multicolumn{1}{l}{$\begin{array}{l}\text { Sum of } \\
\text { Squares }\end{array}$} & df & Mean Square & F & Sig. \\
\hline 1 & Regression & 480.715 & 1 & 480.715 & 45.90 & \multicolumn{1}{c|}{.000} \\
& Residual & 1026.195 & 98 & 10.471 & 8 & \\
& Total & 1506.910 & 99 & & & \\
\hline
\end{tabular}

a. Predictors: (Constant), KUALITASLK

b. Dependent Variable: KINERJA

(Sumber: Data diolah SPSS)

Tabel 7, uji pengaruh simultan ini dapat dilihat dari p-value significant sebesar 0.000. Arti signifikan pada tingkat signifikansi 0,05 yang berarti variabel independen dapat digunakan pada penelitian ini dapat memprediksi variabel dependen yang ada pada penelitian ini.

\section{Koefisien Determinasi}

Tabel 8 menunjukkan koefisien determinasi pada tabel ini, hasil perhitungan $\mathrm{R}^{2}$ dengan menggunakan aplikasi SPSS.

\section{Tabel 8. Koefisien Determinasi}

Model b

Summary

\begin{tabular}{|c|r|r|r|r|l|}
\hline Model & $\mathrm{R}$ & R Square & $\begin{array}{l}\text { Adjusted } \\
\mathrm{R} \\
\text { Square }\end{array}$ & $\begin{array}{l}\text { Std. Error of } \\
\text { the } \\
\text { Estimate }\end{array}$ & $\begin{array}{l}\text { Durbin- } \\
\text { Watson }\end{array}$ \\
\hline 1 & $\begin{array}{l}.565 \\
\mathrm{a}\end{array}$ & $\begin{array}{c}.31 \\
9\end{array}$ & .312 & $\begin{array}{l}3.2359 \\
5\end{array}$ & 2.065 \\
\hline
\end{tabular}

a. Predictors: (Constant), KUALITASLK

b. Dependent Variable: KINERJA

Tabel 8, menunjukkan bahwa diperoleh nilai R sebesar 0,565 dan Adjusted R Square $\left(\mathrm{R}^{2}\right)$ sebesar 0.312 atau 31.2\%. Koefisien determinasi atau Adjusted $\mathrm{R}$ Square $\left(\mathrm{R}^{2}\right)$ sebesar 0.312 memberi pengertian bahwa $31.2 \%$ kinerja usaha UMKM dapat dijelaskan oleh variabel kualitas laporan keuangan, sedangkan 68,8\% dijelaskan oleh variabel lainnya yang tidak dimasukkan model regresi ini. Sehingga dapat disimpulkan bahwa terdapat faktor lain sebesar $68,8 \%$ yang dapat dijelaskan oleh variabel lain yang berpengaruh terhadap kinerja UMKM.

\section{Pembahasan Hasil Penelitian}

Hasil analisis dan pengujian yang dilakukan maka dapat disimpulkan bahwa terdapat pengaruh antara kualitas laporan keuangan terhadap kinerja usaha UMKM.Hal ini berarti peningkatan kinerja umkm akan akan terlihat seiring meningkatnya kualitas laporan keuangan. Laporan keuangan merupakan catatan informasi keuangan suatu entitas dalam satu periode akuntansi untuk melihat kinerja entitas tersebut.

Laporan keuangan yang berkualitas akan membantu para pelaku UMKM untuk memperoleh pinjaman modal dari sektor perbankan melalui program Kredit Usaha Rakyat. Selain itu laporan keuangan juga dapat menunjukkan sehat atau tidaknya suatu usaha tersebut. Dengan kata lain, laporan dan catatan keuangan dapat menjadi salah satu tolak ukur kunci kesuksesan bisnis. Untuk melihat informasi kinerja UMKM dapat ditemukan dalam informasi mengenai penghasilan dan beban selama suatu periode pelaporan, dan disajikan dalam 
laporan laba rugi (Ikatan Akuntansi indonesia, 2016).

Menurut (Wijaya, 2019), implementasi SAK ETAP bagi pelaporan keuangan UMKM industri kreatif sangat diharapkan untuk meningkatkan kualitas laporan UMKM. Dari hasil pengujian hipotesis hanya faktor informasi dan sosialisasi yang dinilai berpengaruh terhadap pemahaman pelaku UMKM terkait SAK ETAP. Sementara faktor-faktor lain seperti tingkat pendidikan, latar belakang pendidikan ukuran usaha, dan lama usaha berdiri tidak berhasil mendukung hipotesis penelitian. Tingkat pemahaman pelaku UMKM menjadi kendala utama untuk melakukan implementasi SAK ETAP. Sebagian besar responden dengan tingkat pendidikan yang rendah, latar belakang non akuntansi serta dari usaha yang tergolong mikro menjadi argumen yang mungkin sesuai untuk menjelaskan rendahnya tingkat pemahaman terkait SAK ETAP. Sehingga perlu perhatian banyak pihak untuk membentuk UMKM khususnya industri kreatif di Kota Banjarmasin untuk dapat mengimplementasikan SAK ETAP bagi tumbuh kembang usahanya.

Peneliti (Almujab et al., 2017) menyatakan bahwa Penyusunan laporan keuangan yang berkualitas dengan menggunakan standar akuntansi keuangan berbasis ETAP juga memungkinkan perusahaan dapat dengan mudah mengembangkan usahanya. Laporan keungan berkualitas yang tersaji tentu akan menimbulkan kepercayaan publik terhadap usaha yang dijalankan sehingga sangat memungkinkan bagi perusahaan untuk terus meningkatkan prospek usaha dengan melakukan tambahan pinjaman modal kepada lembaga keuangan.

(Afif dan Mulyani, 2016) menyatakan bahwa persepsi pengusaha terhadap akuntansi telah cukup baik, hanya terhambat oleh kurangnya pengetahuan tentang standar akuntansi. Hasil penelitian juga menampilkan gejala latar belakang pendidikan itu, panjang bisnis, ukuran bisnis, sikap, subyektif norma, kontrol perilaku, minat dan pemahaman pengusaha atas standar menjadi penentu persepsi tentang pentingnya akuntansi dan SAK Implementasi ETAP pada UKM Binaan PT Telkom Tbk. 


\section{KESIMPULAN DAN SARAN \\ Kesimpulan}

Hasil penelitian ini menunjukkan bahwa kualitas laporan keuangan berpengaruh signifikan terhadap kinerja usaha UMKM. Nilai signifikan kualitas laporan keuangan sebesar 0,00, nilai ini signifikan apabila dibandingkan dengan tingkat signifikansinya, yaitu $\alpha=0.05$, dimana $0.00<$ 0.05. Selain itu, diperoleh t_hitung sebesar 6.776 dan t_tabel sebesar 1.984. Dengan demikian tampak bahwa t_hitung > t_tabel, maka H1 diterima. Oleh karena itu, disimpulkan bahwa kualitas laporan keuangan berpengaruh secara parsial terhadap kinerja usaha UMKM.

\section{Saran}

Masih rendahnya kualitas laporan keuangan yang hasilkan oleh UMKM ini, maka diharapkan untuk berbagai pihak yang terkait dan bersentuhan dengan kepentingan UMKM (seperti perbankan, Kementrian Pajak) untuk dapat mendorong agar UMKM untuk menyediakan laporan keuangan yang baik dan bagus lagi.

\section{DAFTAR PUSTAKA}

Afif, M. Mulyani, S. (2016). Determinants Analysis The Importance of Accounting, Quality of Financial Statements, and Implementation of qFinancial accounting standards for entities without public accountability (SAK ETAP) on SME Fostered by PT. Telkom TBK', pp. 17. doi: 10.2991/imm-16.2016.1.

Almujab, S. et al. (2017). Pengaruh Akuntansi Berbasis Etap Terhadap Kualitas Laporan Keuangan UMKM. Jurnal Riset Akuntansi dan Keuangan 5(3), pp. 1541-1550. doi: 10.17509/jrak.v5i3.9217.

Baridwan, Z. Kresnawati, E. (2016). Pengaruh Program Opsi Saham Manajamen terhadap Kinerja Perusahaan: Analisis Teori Keagenan dan House Money Effect. Simposium Nasional Akuntansi XIX Padang.

Futri, P. S. and Juliarsa, G. (2014). Pengaruh Independensi, Profesionalisme, Tingkat Pendidikan, Etika Profesi, Pengalaman, Dan Kepuasan Kerja Auditor Terhadap Kualitas Audit Pada Kantor Akuntan Publik Di Bali. Jurnal Akuntansi Fakultas Ekonomi dan Bisnis Universitas Udayana ( Unud ), Bali , Indonesia.7(2):44-461.

Ikatan Akuntansi indonesia, I. (2016). Standar Akuntansi Keuangan Entitas Mikro, Kecil, dan Menengah. Sak Emkm, (4), pp. 2017-2019.

Martauli, E. D. (2019). Pengaruh Faktor Eksternal Dan Internal Terhadap Kinerja Usaha Wanita Wirausaha Kerupuk Udang Di Kabupaten Tanjung Jabung Timur Jambi. Journal of Integrated Agribusiness. doi: 10.33019/jia.v1i1.1020.

Mulyani, S. (2014). Faktor-Faktor Yang Mempengaruhi Kualitas Laporan Keuangan Pada Umkm Di Kabupaten Kudus Kata. Jdeb,11(2):137-150.

Murti, A. K. et al. (2018). SAK ETAP, Kualitas Laporan Keuangan dan Jumlah Kredit yang diterima UMKM. Ekuitas: Jurnal Pendidikan Ekonomi. doi: 10.23887/ekuitas.v6i2.16300.

Munizu, M. M. (2013). Total Quality Management (TQM) Practices toward Product Quality Performance: Case at Food and Beverage Industry in Makassar, Indonesia', IOSR Journal of Business and Management. doi: 10.9790/487x-0925561.

Ningtiyas, J. D. A. (2017). Penyusunan Laporan Keuangan UMKM Berdasarkan Standar Akuntansi Keuangan Entitas Mikro, Kecil dan Menengah (SAK-EMKM) (Study Kasus Di UMKM Bintang Malam Pekalongan). Riset \& Jurnal Akuntansi.

Putra, W. E. (2017). Analisis Faktor - Faktor Yang Mempengaruhi Kualitas Laporan Keuangan Pemerintah Daerah (Studi Empiris Pada Pemerintah Kota Jambi)', Jurnal Riset Akuntansi Terpadu. doi: 10.35448/jrat.v10i2.4259.

Rudiantoro, R. and Siregar, S. V. (2012). Kualitas Laporan Keuangan Umkm Serta Prospek 
Implementasi SAK ETAP. Jurnal Akuntansi dan Keuangan Indonesia. 9(2): 1-21. doi: 10.21002/jaki.2012.01.

Sudayanto, Ragimun, Rahma, R. (2011)/ Starategi pemberdayaan UMKM menghadapi pasar bebas ASEAN', Universitas Negeri Jember.

Utami, E. N. Mulyaningsih, H. D. (2016) Pengaruh Kompetensi Kewirausahaan Terhadap

Kinerja UMKM. Majalah Bisnis Dan IPTEK.

Wibowo, A. Kochendoerfer, B. (2011) 'Selecting BOT/PPP infrastructure projects for government guarantee portfolio under conditions of budget and risk in the indonesian context', Journal of Construction Engineering and Management. doi: 10.1061/(ASCE)CO.19437862.0000312 .

Wijaya, K. (2019). Pengaruh Kualitas Laporan Keuangan Terhadap Umkm Serta Prospek Implementasi SAK ETAP', ECOBISMA (JURNAL EKONOMI, BISNIS DAN MANAJEMEN). doi: 10.36987/ecobi.v6i2.9. 
INVENTORY:Jurnal Akuntansi

ISSN 2597-7202 (Print); ISSN 2613-912X (Online)

Vol. 5, No. 1, April 2021, Hal 11-

Tersedia Online: http://e-journal.unipma.ac.id/index.php/inventory 